\title{
REMARKS ON THE PHILOSOPHY OF LAW IN BRAZIL IN THE TWENTIETH CENTURY*
}

\author{
OBSERVACIONES SOBRE LA FILOSOFÍA DEL DERECHO \\ EN BRASIL EN EL SIGLO VEINTE \\ Ronaldo Porto MACEDO JUNIOR \\ Carla Henriete Bevilacqua PICCOLO**
}

\begin{abstract}
Resumen:
Para emprender el estudio del desarrollo de la filosofia del derecho en Brasil en el siglo veinte, el artículo se divide en 4 partes distintas: La primera se enfoca al fundamento de la educación superior en el país. La segunda describe el nacimiento y desarrollo de un tipo de filosofia del derecho que prácticamente ocupa todo el siglo veinte, un tipo de filosofia del derecho que se caracteriza por una fuerte presencia de un pensamiento jurídico retórico y humanista, el cual carecía de contornos precisos entre la sociología, historia, filosofia general y filosofia jurídica. La tercera parte destaca el nacimiento de una filosofia en Brasil propia de la academia universitaria, profesional y técnica, la cual coexiste con la filosofía del derecho que se genera en las facultades de derecho. Esta tercera etapa inicia con la fundación de la Universidad de Sao Paulo en 1934 y sigue una "historia paralela" con la filosofia que continúa hasta nuestros días. Se caracteriza por una obsesión con los aspectos metodológicos, una precisión conceptual por otra parte y una orientación hacia la historia de

* This is an extended and modified version of the essay Pattaro, Enrico \& Roversi, Conrado. "Philosophy of law in Brazil in the twentieth century". In: A Treatise of Legal Philosophy and General Jurisprudence, New York, v. 12, Springer 2014. On print.

** Ronaldo Porto Macedo Junior, Associate Professor at USP Law School and Direito GV, ronaldo.macedo@terra.com.br

Carla Henriete Bevilacqua Piccolo, Master in Law at USP.
\end{abstract}

PROBLEMA

Anuario de Filosofia y Teoría del Derecho,

Núm. 8, enero-diciembre de 2014, pp. 179-224 
Esta revista forma parte del acervo de la Biblioteca Jurídica Virtual del Instituto de Investigaciones Jurídicas de la UNAM www.juridicas.unam.mx

http://biblio.juridicas.unam.mx

MACEDO / PICCOLO

la filosofia con autores clásicos por la otra, la cual, por cierto, guarda un relativo interés en la filosofia del derecho entendida en sentido estricto. Una cuarta etapa, que inicia en la primera década del siglo veintiuno, se caracteriza por una limitada agenda de discusiones y trabajo teórico hecho por filósofos profesionales y algún trabajo hecho en las facultades de derecho.

\title{
Palabras clave:
}

Filosofia del derecho, enseñanza del derecho, recepción dela filosofia del derecho, cultura jurídica, Brasil.

\begin{abstract}
:
The text divides the development of Philosophy of Law in Brazil in twentieth century in four separate stages. The first starts with the foundation of higher education in Brazil and goes through the turn of the nineteenth century. The second stage characterizes the emergence and development of a type of legal philosophy that lasts almost through the entire twentieth century. This could be characterized by the presence of a humanist and rhetoric legal thinking, often lacking clear boundaries between sociology, history, general philosophy and legal philosophy. The third stage is marked by the emergence of a professional, technical, university-oriented academic philosophy in Brazil and its coexistence with the philosophy of law produced in law schools. This stage began with the foundation of the University of Sao Paulo in 1934 and it follows a "parallel history" of Philosophy in Brazil, remaining until our days. Obsession with methodologies, conceptual accuracy and orientation to the history of philosophy, especially among classical authors, are its distinguishing features, as it is little concerned with philosophy of law in a strict sense. A fourth stage, which began in the first decade of the twenty-first century, is marked by a reduced agenda of discussions and theoretical work by professional philosophers and some works performed by law schools.
\end{abstract}

Keywords:

Philosophy of Law, Legal Educatión, Law Schools, Jurisprudential Reception, Brazil. 
Esta revista forma parte del acervo de la Biblioteca Jurídica Virtual del Instituto de Investigaciones Jurídicas de la UNAM www.juridicas.unam.mx

http://biblio.juridicas.unam.mx

REMARKS ON THE PHILOSOPHY OF LAW IN BRAZIL

Summary: I. Introduction. II. Legal Courses in Brazil and the Buildup of the National Elite. The Legal Inheritance before the Twentieth Century. III. The Legal Philosophical Thought of the Beginning of the Twentieth Century. IV. The Creation of the School of Philosophy: Professional Philosophers. V. The Tradition of Legal Philosophers and the Brazilian Institute of Philosophy (IBF). Miguel Reale: a New Chapter in the Philosophy of Jurists. VI. The 1960s: Increasingly Separate Paths. VII. The Beginning of a Difficult Dialogue and a Risky Overview of Present Moment. VIII. Bibliography.

\section{INTRODUCTION}

It is commonly noted that the problem of philosophy begins with its own definition. Brazilian philosophical thoughts in the twentieth century are under the same preliminary issue, which relates to determining what should be considered philosophical production and, especially, the Philosophy of Law in Brazil. Moreover, Philosophy of law studies philosophical problems raised by the practice of law and is somehow parasitic upon the philosophy of ethics, mind, and action.

Law schools have played in Brazil, like other Western countries, a key role in disseminating and expanding a generically called humanistic culture that transcended the limits of law itself as a discipline of knowledge. For this reason, this text is divided into four separate stages. The first one starts with the foundation of higher education in Brazil and goes through the turn of the nineteenth century. We will very briefly recast this issue just to make the rest of the arguments concerning XX century more intelligible. The second stage characterizes the emergence and development of a type of legal philosophy that lasts almost through the entire twentieth century. This could be characterized by the presence of a humanist and rhetoric legal thinking, often lacking clear boundaries between sociology, history, general 
Esta revista forma parte del acervo de la Biblioteca Jurídica Virtual del Instituto de Investigaciones Jurídicas de la UNAM www.juridicas.unam.mx

http://biblio.juridicas.unam.mx

MACEDO / PICCOLO

philosophy and legal philosophy. The third stage is marked by the emergence of a professional, technical, university-oriented academic philosophy in Brazil (especially as an outcome of the creation of the first schools of philosophy) and its coexistence with the philosophy of law produced in law schools. This stage began with the foundation of the University of Sao Paulo in 1934 and it follows a "parallel history" of Philosophy in Brazil, remaining until our days. Obsession with methodologies, conceptual accuracy and orientation to the history of philosophy, especially among classical authors, are its distinguishing features, as it is little concerned with philosophy of law in a strict sense. A fourth stage, which began in the first decade of the twenty-first century, is marked by a reduced agenda of discussions and theoretical work by professional philosophers and some works performed by law schools.

\section{LEgal Courses in BRAZIL AND THE Buildup \\ of the National Elite. The Legal Inheritance \\ Before the Twentieth CEnTURY}

\section{Overview}

The History of Philosophy of Law in Brazil dates back to colonial times, which makes it unconceivable to separate it from the Philosophy of Law in Portugal. The first law graduates in Brazil were educated in Europe, especially in Portugal, where they absorbed the culture and tradition of Lusitanian legal studies and where they came from to play various roles in the cultural, political and economic elite in Brazil. ${ }^{1}$ A similar situation is found in most of Latin American countries of that time.

1 Lopes, J. R. L., O direito na história, lições introdutórias, São Paulo, Max Limonad, 2000; Venâncio Filho, A., Das arcadas ao Bacharelismo, São Paulo, Perspectiva, 1977; Adorno, S., Os aprendizes do poder: o bacharelismo liberal na politica brasileira, Rio de Janeiro, Paz e Terra, 1988. 
Esta revista forma parte del acervo de la Biblioteca Jurídica Virtual del Instituto de Investigaciones Jurídicas de la UNAM www.juridicas.unam.mx

http://biblio.juridicas.unam.mx

REMARKS ON THE PHILOSOPHY OF LAW IN BRAZIL

One of the earliest philosophical manifestations in Brazilian was seen upon the Brazilian independence in 1822, before the foundation of the two law schools in 1827. Influenced by the French Enlightenment, Father Diogo Antônio Feijó (1784-1843) and Martim Francisco (1775-1844) brought the first courses on some of the main philosophers of the French Revolution. Martim Francisco has even taught a course on Kant in Brazil between 1805 and 1810, which certainly represented a remarkable fact given that Kantianism would take longer to get to core countries such as France. It is worth noting, however, that Kant and the Enlightenment were "received" more as expressions of liberalism than as an outcome of the philosophical revolution that they would represent, in particular, in epistemology. ${ }^{2}$

As late as in 1827, the newly independent Brazil organized, upon decree of its emperor, the first law courses, one in the Northeastern portion of Brazil, in Olinda, later moved to Recife, and another in the Southeast, in São Paulo. That was the foundational moment not only for legal studies in Brazil, but also for humanistic higher education. However, a greater distance between Portuguese and Brazilian intellectuality was only witnessed many decades later. The creation of law courses, however, stems directly from a new political institutional design for the country and brought new intellectual influences like romanticism in literature and liberal ideas in politics.

Hence, the unveiling of the national state and liberalism emerge as two central issues in the setup of the first Brazilian reflection on philosophy of law. ${ }^{3}$ Interestingly, however, a liberal legal-philosophical consciousness lived ambivalently with the maintenance of slavery, abolished in Brazil as late as in 1888. As pointed out by José Reinaldo Lima Lopes, "A liberal and enlightened revolutionary perspective

2 Ferraz Jr, T. S., "A filosofia do direito no Brasil”, Revista Brasileira de Filosofia, São Paulo, vol. XLV, Fasc. 197 - January-February-March, 2000, pp. 12-30.

3 Lima Lopes, J. R., op. cit. 
Esta revista forma parte del acervo de la Biblioteca Jurídica Virtual del Instituto de Investigaciones Jurídicas de la UNAM www.juridicas.unam.mx

http://biblio.juridicas.unam.mx

MACEDO / PICCOLO

capable of undertaking large demonstrations to defend individual freedom, coexisted uneasily -from a theoretical point of view - with slavery. But it took up a number of arguments to rationalize this restricted universalization of civil rights. Even the American Revolution and the French Revolution had to live with this kind of contradiction ... And the revolutionary and civilizing France, after abolishing slavery in its territory and colonies, as ordered by the Convention of February 4, 1794, had second thoughts in 1802, and enhanced both slavery and trafficking in the colonies, putting an end to equal rights". ${ }^{4}$ Such non-Republican thought, however, remained alive during this period. Among its representatives, José Maria Corrêa de Sá e Benevides (1833-1901), from the faculty of the Faculdade de São Paulo, stood apart as a follower of theological natural law, relying especially on the doctrine of the Catholic Church. He repelled Comte' positivism firstly because it is not based on belief in God and immortality of the soul and, secondly, because it asserts that morality should be subordinate to sociology. 5

The Law Schools, however, were not only law-teaching sites. In general, generalist education had a strong humanistic component. More often than not, students would engage in discussions on arts, politics, literary criticism and science, as well as laws. Classic writers of Brazilian literature, including Álvares de Azevedo, Castro Alves and José de Alencar are some examples of the dominant type of education. The impact of Law Schools is also strongly felt in the development of social sciences in Brazil. Virtually all classical social thinkers from Brazil came from law schools.

This generalist and interdisciplinary scenario promoted the first intellectual studies and efforts towards a Philosophy of Law. First, it is born as a philosophy of jurists trained in a rhetoric tradition commonly known as lawyeristic (bacharelismo), marked by classical and general humanism,

4 Ibidem, p. 351.

5 Nader, P., Filosofia do direito, Rio de Janeiro, Forense, 2000, p. 255. 
Esta revista forma parte del acervo de la Biblioteca Jurídica Virtual del Instituto de Investigaciones Jurídicas de la UNAM www.juridicas.unam.mx

http://biblio.juridicas.unam.mx

REMARKS ON THE PHILOSOPHY OF LAW IN BRAZIL

generalism, erudition, influenced by the Belle Époque and lacking academic and methodological accuracy in treating authors and ideas. The national elite ultimately reverberates the European philosophical theoretical debate without necessarily digesting it with the rigors with which it was developed and designed in European cities, especially Paris and Lisbon. It can be said that the legal philosophical intellectual production of that time represents much more an effort to disseminate the mainstream of European thought than the production of a national philosophical thought. ${ }^{6}$ The Brazilian social thought had evolved differently, as it focused on Brazilian facts and realities, gaining its own identity and, to some unique extent, long before the general philosophy and philosophy of law in particular. Such eclectic academic environment, a lawyeristic one, ${ }^{7}$ is still alive and present in most Brazilian law schools of the twentyfirst century. Nevertheless, some works of intellectual value were produced by these legal philosophers.

Despite this, we can state that the way European ideas have spread across Brazil marks a field of originality, though, in most cases, the incorporation of certain ideas is less due to the philosophical merits than to its political and ideological function in the Brazilian political and legal scenario. ${ }^{8}$

\section{The Main References of the Period}

Even during the colonial period, a case in point was Tomás Antônio Gonzaga (1744-1809), author of the Tratado de Direito Natural. He developed his libertarian political ideas and was sent to exile for having allegedly participated in the movement known as Minas Conspiracy (Inconfidência

6 Reale, M., Filosofia em São Paulo, 2nd ed., São Paulo, Grijalbo, 1976, p. 9.

7 Venâncio Filho, op. cit.

8 Reale, Filosofia..., op. cit., p. 137. 
Esta revista forma parte del acervo de la Biblioteca Jurídica Virtual del Instituto de Investigaciones Jurídicas de la UNAM www.juridicas.unam.mx

http://biblio.juridicas.unam.mx

MACEDO / PICCOLO

Mineira), a famous chapter in Brazilian history in which the Portuguese authority was challenged by the settlers. Although his natural law lessons with theological nuances did not bring major innovations, they consisted of a systematic and clear outline of the thinking of some authors, including Heinécio, Puffendorf and Grotius, the latter criticized for designing a natural law that was apart of God's existence.

In the nineteenth century, several names are related to the Philosophy of Law, usually professors of Sao Paulo. José Maria de Avelar Brotero (1798-1878) was the first Professor of Natural Law (eventually replaced by Philosophy and General Theory of Law) of the newly established Law School of São Paulo. In 1829, he published a compendium introducing the subject of Natural Law to be used by his students. His classes were underpinned by the authors that included Mably, Holbach, Helvetius, Perreau and Cabanis and exposed avant-garde opinions, clearly at odds with the prevailing doctrine in Portugal, such as the concept that marriage was an agreement based on mutual consent, and divorce was the only possible moral solution in the absence of such a mutual agreement and spouses should have equal rights.

The foundation of the Law School of Sao Paulo in 1827 arises when, somehow, European philosophical influences were already present (especially Grotius, Pufendorf, Heinéccio, Filangieri, Beccaria, Bentham and Adam Smith). However, the foundation of the legal course consolidated this influence. ${ }^{9}$

As seen before, Kant was already known. However, late in the 1830 s, Kantianism began to wield a more powerful influence, particularly through the work of a smaller Kantian, named Karl Christian Krause (1791-1832), brought to Brazil by the hands of a German immigrant, Julius Frank (1808-1841), who taught in prep schools for admission to law school. This Kantian presence, though somewhat am-

9 Lima Lopes, op. cit., p. 338. 
Esta revista forma parte del acervo de la Biblioteca Jurídica Virtual del Instituto de Investigaciones Jurídicas de la UNAM www.juridicas.unam.mx

http://biblio.juridicas.unam.mx

REMARKS ON THE PHILOSOPHY OF LAW IN BRAZIL

biguous, is felt on the thought of Tobias Barreto (18391889), one of the jurists-philosophers who stands out in this period. The professor from the "School of Recife" represented a significant effort to disengage the Brazilian legal thought from the old Portuguese Law, still very rooted in praxis and a scholar style. He rebelled precisely against Praxis and Scholar Styles, taking natural sciences as a methodological model to be followed also by legal science. Driven away from the School of Exegesis and Pandectists, which had the peak of his influence in the first half of the nineteenth century, Barreto was one of the authors who most contributed to bringing sociological and anthropological studies to jurists. Barreto combined in a syncretic and little consistent way the evolutionism of Ernst Haeckel, a reputable author among cult readers of Brazil, and also Jhering and Herman Post, with the Krausist Kantianism. He forged a kind of sociology of Natural Law. Another professor of Natural Law in Sao Paul was João Theodoro Xavier (1828-1878), also responsible for the dissemination of Karl Krause and Heinrich Ahrens' ideas. These theoretical references were remarkable in the education of another important Brazilian jurist and thinker of the nineteenth century, which forecasts his influence into the twentieth century, Clovis Bevilacqua (1859-1944).

It is important to remember, as highlighted that this generation of jurists is also marked by the strong influence of a "practical approach" of Portuguese philosophy, completely averse to pure metaphysics. ${ }^{10}$ Perhaps this is a satisfactory explanation for the fact that there had not been in Brazil a philosopher of Law itself, but, for example, great Private Law theorists who used their eclectic philosophy knowledge to build their works. According to Clovis Bevilacqua responsible for drafting the Civil Code of 1916, "if some day we could produce further philosophical works, it will not emerge from the heights of metaphysics" [apud COSTA:

10 Costa, J. C., Contribuição à história das idéias no Brasil, Rio de Janeiro, José Olympio, 1956, p. 438. 
Esta revista forma parte del acervo de la Biblioteca Jurídica Virtual del Instituto de Investigaciones Jurídicas de la UNAM www.juridicas.unam.mx

http://biblio.juridicas.unam.mx

MACEDO / PICCOLO

1956, 442 my translation].11 In fact, the "practical approach" that dominated the works in Law Schools would not allow us expecting something different, at least in the near future. The practical approach, however, was not synonymous with lack of theories or reflection on Law. Influenced by the evolutionism of Tobias Barreto, Bevilacqua combined it with the idea that the Law would represent fight (Jhering)

Also noteworthy is the fact that, around 1854, João Chrispiniano Soares (1809-1876), professor of Roman Law at the School of Law in São Paulo, embraced the influence of pandectism and Savigny's ideas. This influence was to be remarkable on the model of exegesis and systematization followed by several prominent jurists and coders, such as Bevilacqua, Teixeira de Freitas and Conselheiro Ribas. In the latter's Civil Law course, we can also see notable influences and a large number of quotations from German writers, including Arndts, Buchardi, Cramer, Disksen, Glück, Puchta and others. ${ }^{12}$

Teixeira de Freitas (1816-1883) drafted a General Code, supposed to be above other civil, criminal and procedural laws, containing standards for the application, interpretation, validity and term of effectiveness, as well as criteria for resolving conflicts of laws in time and space. Although his work and efforts were not accepted in Brazil, he inspired the logical structure of the Civil Code of the Empire of Japan of 1898, the Laws and General Rules and Sources of Law of the Vatican in 1929, the Italian Civil Code of 1942, and the review of the French Civil Code in the 1930s. In Latin America, his works served as a basis for the civil codes of Argentina, Paraguay and Uruguay. This is a further example of an intellectual man of legal sciences, cultured and learned on philosophy, but whose intellectual potential became famous for his role in practical matters such

11 Ibidem, p. 442.

12 Ribas, A. J., Curso de direito civil brasileiro, Rio de Janeiro, J. R. dos Santos, 1915. 
Esta revista forma parte del acervo de la Biblioteca Jurídica Virtual del Instituto de Investigaciones Jurídicas de la UNAM www.juridicas.unam.mx

http://biblio.juridicas.unam.mx

REMARKS ON THE PHILOSOPHY OF LAW IN BRAZIL

as the creation of a code of laws. His work is marked by the traits of the Brazilian legal thinking of this time, little focused on purely metaphysical questions and more oriented to practical issues. However, the genius of Teixeira de Freitas shows an especially deeper concern for philosophical dimensions of private law, rarely seen among his peers. ${ }^{13}$

Silvio Romero (1851-1914) is another prominent author in this turn of the century, responsible for disseminating in Brazil an eclectic concept of Spencerian evolutionism and scientific-positive orientation to the Law, heavily influenced by the English evolutionist Thomas Huxley ${ }^{14}$. Pedro Lessa (1859-1921), in Sao Paulo, was also for a "positive" philosophy, adopting the principles and methods of Comte, Spencer, Stuart Mill, among others ${ }^{15}$. Despite a strong opposition from representatives of Scholasticism in Brazil especially Soriano Sousa (1833-1895), from the North, and João Mendes Junior (1856-1923) from the South this scientific-positive approach of Law, where we can include the names of Clovis Bevilacqua and Pontes de Miranda, prevailed until late in the 1930s. Since then, new doctrinal currents have been absorbed by the Brazilian legal thought, such as Husserl's phenomenology, existential philosophy and Marxism.

In short, positivism and its scientistic ambition, evolutionism and classical scholasticism on the one hand, as theoretical frameworks, and a strong orientation to legal practice, mark the inception of the Brazilian legal thinking. In the words of Lima Lopes, "The theoretical discussion in

13 His most important works are Teixeira de Freitas, A., Código Civil Esboço, Rio de Janeiro, Typographia Universal de Laemmert, 1864.

14 On Philosophy of Law, he wrote Romero, S., Ensaios de philosophia do direito, Recife, Companhia Impressora, 1885. And also Romero, S., A filosofia no Brasil: ensaio crítico, Porto Alegre, Tipografia de Deutsche Zeitung, 1878.

15 See Lessa, P., 1912. Estudos de filosofia do direito, Rio de Janeiro, F. Alves. and also Lessa, P., Dissertações e polêmicas - Estudos jurídicos, Rio de Janeiro, Tipografia do Jornal do Comércio, 1909. 
Esta revista forma parte del acervo de la Biblioteca Jurídica Virtual del Instituto de Investigaciones Jurídicas de la UNAM www.juridicas.unam.mx

http://biblio.juridicas.unam.mx

MACEDO / PICCOLO

the second half of the century (the generation of 1870, the so-called Brazilian Enlightment) shows the need to overcome the traditionalist Natural Law that prevailed. The alternative that emerges is the science: here, as almost everywhere, what goes into effect are forms of naturalism". ${ }^{16}$ These features go beyond the nineteenth century to mingle with the beginning of the twentieth century, as discussed below. This new approach to legal thinking dealt with a often mentioned "dilemma between the real country and the legal country", the "Living Law and the Law doctrinally constructed", offering a clear response to it. According to it that science of law should focus on the real law and abandon the metaphysics of idealistic legal doctrine.

III. The Legal Philosophical Thought of the Beginning of the Twentieth Century

The late nineteenth century is the beginning of the Republican decentralization and eventually consolidated the state of São Paulo as the new hub of the Brazilian economy due to the coffee-centered economy. This fact will have an impact both from a cultural and from a philosophical point of view. These changes underpin the emergence, early in the twentieth century, of a new emphasis on reflection wedded to dogmatic practice, less stick to the dilemma between the Living Law and the Law doctrinally constructed. Some influential works mark out the new methodological requirements that will resonate in the work of legal philosophers. João Mendes Junior, for example, tried to outline a role for philosophy of law as a kind of basic doctrine of legal science. Francisco Campos assigned to legal doctrine the task of devising general principles of law and establishing how to build up the legal phenomenon. Pedro Lessa and João Arruda focused on methodological issues concerning scientific study of law. Pontes de Miranda also followed a scien-

16 Lima Lopes, op. cit., p. 341. 
Esta revista forma parte del acervo de la Biblioteca Jurídica Virtual del Instituto de Investigaciones Jurídicas de la UNAM www.juridicas.unam.mx

http://biblio.juridicas.unam.mx

REMARKS ON THE PHILOSOPHY OF LAW IN BRAZIL

tific methodological path. However, in his view sociology is the scientific model that should guide legal investigation. ${ }^{17}$

From a cultural standpoint, the last decades of the nineteenth century had generated the Brazilian Enlightment ${ }^{18}$, which stemmed from a direct contact with the European culture and particularly with France. It produced the ideas of evolution, biological and social Darwinism, positivism and materialism. These ideas are embraced by the Brazilian local elites, who draw themes and aspects that are closer to them. Positivism has an enormous bearing on the military and scientific arena. However, it is not similarly present in the Schools of Law, the main site of philosophical conjectures of that time. As pointed out by João Cruz Costa, "positivism was incorporated into the Portuguese and Brazilian culture not for its philosophical merits, but because it served a political-historical movement. ${ }^{19}$

The 1920s and 1930s have profoundly influenced the legal thought of all the European legal tradition. In Brazil, it was not different. Political changes are profound and extreme. Huge ideological conflicts between socialism, liberalism, fascism and corporatism would leave footprints in both the public and in the private law. In the private arena, reforms to the Code of Obligations and Family are planned. Although such reforms were not brought to fruition, they opposed liberal thoughts to fascist corporatism (particularly influential in Brazilian labor law and social security policies). ${ }^{20}$ With this respect, a case in point is the legal theoretical debate, which stroke the Vargas Era (period Brazil was governed by President Getulio Vargas 1930-1945), between two disagreeing views on the role of jurists and the role of private law. The main character of such debate is

17 Ferraz Jr., T., “A filosofia do direito no Brasil”, Revista Brasileira de Filosofia, São Paulo, vol. XLV, Fasc. 197 - January-February-March 2000.

18 As started Barros, R. S. M., A ilustração brasileira e a idéia de universidade, São Paulo, EDUSP, 1927.

19 Reale, Filosofia..., cit., p. 137. Translation mine.

20 Lima Lopes, op. cit., p. 382. 
Esta revista forma parte del acervo de la Biblioteca Jurídica Virtual del Instituto de Investigaciones Jurídicas de la UNAM www.juridicas.unam.mx

http://biblio.juridicas.unam.mx

MACEDO / PICCOLO

Waldemar Ferreira (1865-1964), Professor of the School of Law of São Paulo, and Oliveira Vianna (1883-1951), Legal Adviser for the Ministry of Labor, also a sociologist and jurist, a Professor in Rio de Janeiro. The former makes a classic defense of liberal thought. ${ }^{21} \mathrm{He}$ argues that liberalism is inconsistent with labor courts as those shaped up in a corporatist model in Brazil, completely at odds with the standards of private law. Oliveira Vianna defends the need for a strong State intervention to implement a national development project. ${ }^{22}$ Vianna's corporatist model, successful in the Vargas Era, has considerably impinged the political and legal debate that continued through the following decades.

In the field of Public Law, a comprehensive administrative reform is undertaken under the command of some social thinkers, such as Oliveira Vianna, and philosophers of law, such as Francisco Campos (1891-1968), who authored the Authoritarian Constitutional Charter of 1937 and the reform that created the "Introduction to Science of Law" (mostly focused on the main categories of legal dogmatics). One of the heydays of this reform was the creation of exams for public offices, gradually replacing appointments and allowing the establishment of a professional bureaucracy apart from the traditional patrimonialism and derived from the urban middle class. ${ }^{23}$ However, even late in the 1930's, influential Catholic sectors assembled around Alceu Amoroso Lima (1893-1983) and Priest Leonel Franca (18931948 ) to come up with an alternative to the system of vocational schools. Inspired by the medieval university corporations, which put the science and techniques under the umbrella of philosophy and theology, they shaped up the foundations for a movement that eventually resulted in the

$21 C f$. Ferreira, W., Principios de legislação social e direito judiciário do trabalho, São Paulo, Freitas Bustos, 1938.

22 Vianna, Francisco José de Oliveira, Problemas de direito corporativo, Rio de Janeiro, Livraria José Olympio Ed., 1938.

23 Lima Lopes, op. cit., p. 383. 
Esta revista forma parte del acervo de la Biblioteca Jurídica Virtual del Instituto de Investigaciones Jurídicas de la UNAM www.juridicas.unam.mx

http://biblio.juridicas.unam.mx

REMARKS ON THE PHILOSOPHY OF LAW IN BRAZIL

Catholic University of Rio de Janeiro (Pontificia Universidade Católica do Rio de Janeiro). This environment witnessed a continuing influence of Saint Thomas Aquinas' religious thought, which remained present in the natural law thinking in law schools. ${ }^{24}$

This strongly eclectic positivist, evolutionist and naturalist mindset, which coexisted with a strong presence of the Catholic thought and an inflow of the non-liberal ideas that marked the authoritarian fascist and communist thinking 25 was the dominant intellectual context in Brazil from 1930 to 1940. In 1940, Miguel Reale (1910-2006), published Fundamentos do Direito (1940), which caused a shift in the legal and philosophical scenario of the postwar period. Before analyzing it, we should first describe (as we will do in the next section) a new philosophical intellectual force that began in Brazil with the creation of the University of Sao Paulo.

IV. The Creation of the School of Philosophy: Professional PhILOSOPHERS

1. The Foundation of University of São Paulo (USP) and the "French Mission"

It is worth noting that in general many works concerned with social theory and philosophy of the beginning of the $\mathrm{XX}$ century is made by jurists specialized in other branches of legal dogmatics. This feature of the theoretical and philo-

24 Schwartzman, S., Formação da Comunidade Científica no Brasil, Cia Editora Nacional, 1979, p. 189. Catholic-inspired social thinking has also influenced the Catholic University (PUC) of Sao Paulo, especially through the teaching practices adopted by Montoro, A. F., Estudos de filosofia do direito, 4th ed., São Paulo, Saraiva, 2009.

25 Lamounier, B., "Formação de um pensamento político autoritário na Primeira República. Uma interpretação”, in Fausto, B. (org.), História geral da civilização brasileira, t. III: O Brasil Republicano, 2o. vol., Rio de Janeiro, Bertrand, 1989. 
Esta revista forma parte del acervo de la Biblioteca Jurídica Virtual del Instituto de Investigaciones Jurídicas de la UNAM www.juridicas.unam.mx

http://biblio.juridicas.unam.mx

MACEDO / PICCOLO

sophical production is still strongly present in the contemporary production of "legal philosophers", chiefly targeted at the production of manuals, abstracts and dissemination works affecting the legal publishing market, but these are little used in academic circles outside the law schools. Thus, they constitute a theoretical production "for consumption of law students and jurists", not joining intellectual debates with other university departments. Evidently, such phenomenon is partially linked to the framework of the Brazilian theoretical production in the legal field still predominantly composed of half-time professors, usually lawyers or legal professionals little concerned with academic research.

A turning point in this timeline is the foundation of the University of Sao Paulo (USP) and its School of Philosophy in 1934. This fact profoundly marked the construction of a dashing model for the Brazilian university. Ever since, USP has been the most influential and reputable institution of higher education in Brazil. Although it has not been the first Brazilian university, it was born within Francisco Campos' Reform (Minister of Education and Public Health of Getulio Vargas). Such reform was concerned with the creation of "an administrative and education unit targeted at technically equipping the Brazilian professional elites and enabling an environment conducive to speculative and disinterested vocations, whose fate, essential to the formation of a national culture, is investigation and pure sci ence"26. Before most other universities, USP was born from this new phase of modernization.

For the foundation of USP, in particular for the formation of the School of Philosophy, Sciences and Literature, many foreign professors were hired for almost all fields of knowledge. In the field of humanities, the first full professors included the sociologist Roger Bastide (1898-1974), the political scientist Paul Arbousse-Bastide (1899-1985), the anthropologist Claude Lévi-Strauss (1908-2009), the geog-

26 Schwartzman, op. cit., p. 172. 
Esta revista forma parte del acervo de la Biblioteca Jurídica Virtual del Instituto de Investigaciones Jurídicas de la UNAM www.juridicas.unam.mx

http://biblio.juridicas.unam.mx

REMARKS ON THE PHILOSOPHY OF LAW IN BRAZIL

rapher Pierre Monbeig (1908-1987), the philosopher and psychologist Jean Maugüé (1904-1985) and the historian Fernand Braudel (1902-1985), all of whom came from France at a young age as recent graduates invited by the mathematician Theodoro Ramos (1895-1936), sent to Europe in order to seek a teaching and researching staff. At that time, we used the term "French mission" ("Missão Francesa") to refer to this group of intellectuals who had begun education works in the new academic college. The word "mission", in a contemporary meaning, refers to a group of people who are entrusted with a task, usually in another place or country. But it also carried a connotation that "we were seen as a land of indigenous people who should be indoctrinated". ${ }^{27}$

Whereas, on the one hand, the Brazilian philosophical production, though small, have had a short history, on the other hand, the "French Mission" represented a foundational moment, introducing in Brazil a unique way of philosophizing, more scholarly, methodologically strict, and distant from the lawyeristic style of the past. The concern with a close and structural reading of classical texts was such that the course was gradually taking an increasing bias of History of Philosophy rather than philosophy itself. This fact got glaringly conspicuous with the arrival of the first professors of History of Philosophy, such as Gilles Gaston Granger (1920-) and the strong influence of the structuralism of Martial Guéroult (1891-1976) and Victor Goldschmidt (1914-1981). From 1960 to 1990 the French professors Gérard Lebrun (1930-1999), Michel Debrun (1921-1997), Francis Wolff (1950-), would also be very influential. ${ }^{28}$ Years earlier, in 1936, Professor Émile Bréhier (1876-1952) had also been hired as a professor of Philosophy at the University of the

27 As started Novais, F., "Braudel e a "missão francesa", Estudos avançados, São Paulo, vol. 8, num. 22, Sept./Dec. 1994. Translation mine.

28 Arantes, P. E., Um departamento francês de ultramar, estudos sobre a formação da cultura filosófica uspiana (uma experiência nos anos 60), São Paulo, Paz e Terra, 1994. 
Esta revista forma parte del acervo de la Biblioteca Jurídica Virtual del Instituto de Investigaciones Jurídicas de la UNAM www.juridicas.unam.mx

http://biblio.juridicas.unam.mx

MACEDO / PICCOLO

Federal District in Rio de Janeiro, and also left a lasting impression on future generations.

The French mission has brought a new academic style and rigorous method to the study of Philosophy. This new intellectual moment of philosophy in Brazil has immediately caused, especially in Sao Paulo, a sort of tension with the Philosophy of jurists, until then prevailing in major Brazilian cities like Sao Paulo, Rio de Janeiro and Recife. The differences in methods, approaches and goals marked the seclusion of these two models of philosophical production in Brazil, which have seldom met each other. The seclusion of Philosophy of Law in law schools awaited the end of the twentieth century to dissipate. The academic philosophers, on the other hand, only recently became interested in contemporary philosophy of law and jurisprudence.

\section{The Main References}

The Professor of Philosophy assigned to lead the first moment of philosophical civilizing mission was Jean Maugüé, who taught from 1935 to 1944 . He was later succeeded by his first assistant João Cruz Costa (1904-1978) who, along with Livio Teixeira (1902-1975), would ensure the transmission of the radical reform project that was instituted. ${ }^{29}$ The impact of the French mission also included the Aesthetics Professor Gilda de Mello e Souza (1919-2005) and the second generation of college graduates made up of Brazilian philosophers that marked deeply the future generations, José Arthur Giannotti (1930-), Bento Prado Jr. (19372007), Oswaldo Porchat (1933-) and Ruy Fausto (1935-). Contemporary with this first wave of technical philosophers were French professors Michel Debrun (1921- 1997) and Gérard Lebrun. (1930-1999) This generation was succeeded

29 Ibidem, and also Arantes, P. E., "O bonde da Filosofia. Aspectos da cultura filosófica uspiana nos últimos anos da Rua Maria Antonia (1965-1968)", in Loschiavo dos Santos, Maria Cecília (org.), Maria Antonia: uma rua na contramão, São Paulo, Nobel, 1988. 
Esta revista forma parte del acervo de la Biblioteca Jurídica Virtual del Instituto de Investigaciones Jurídicas de la UNAM www.juridicas.unam.mx

http://biblio.juridicas.unam.mx

REMARKS ON THE PHILOSOPHY OF LAW IN BRAZIL

by other major presences in the Brazilian philosophy, such as Marilena Chauí (1941-), Rubens Rodrigues Torres (1942-), Luis Roberto Salinas Fortes (1937-1987) and in the Philosophy of Law, such as Tércio Sampaio Ferraz Jr. (1941-), who opened up a small chapter of methodological dialogue between the Philosophy of jurists and the technical philosophy that was taught in the School of Philosophy of USP. This first generation did its methodological homework, incorporating the strict academic spirit transmitted by the founders and by other missionaries who had been part of the Department of Philosophy, such as Gilles Gastón Granger (1920-) and Victor Goldschmidt (19141981). ${ }^{30}$ These were responsible for encouraging the process of internationalizing the philosophical education, which virtually required an internship abroad, preferably in France.

The first outcomes of this technical-philosophical education stemmed from a number of structuralist reading studies (taken in a more or less orthodox manner, but always assumed at least as a preliminary step to a study of the History of Philosophy), on several authors who made up the intellectual universe of this generation. The new Brazilian philosophers produced works of close reading on Descartes, ${ }^{31}$ Marx, ${ }^{32}$ among other authors as Espinosa, ${ }^{33}$ kkkkkk

30 Macedo Jr., R. P., "O método de leitura estrutural”, in Macedo Jr., R. P. (org.), Curso de filosofia politica, São Paulo, Atlas, 2008; Goldschmidt, V., "Remarques sur la méthode structurale em histoire de la philosophie", Revista Manuscrito, v. V, n. 2, abr. 1982, Campinas, 1982, p. 130; Moura, C. A. R., "Husserl: intencionalidade e fenomenologia", Mente - Cérebro e Filosofia, São Paulo, num. 5, 2007, p. 13.

31 Teixeira, L., Ensaio sobre a moral de Descartes, São Paulo, Brasiliense, 1990.

32 Giannotti, J. A., Certa herança marxista, São Paulo, Cia. das Letras, 2000; Fausto, R., Dialética marxista, dialética hegeliana, Rio de Janeiro, Paz e Terra, 1997.

33 Chauí, M., A Nervura do Real-Imanência e Liberdade em Espinosa, São Paulo, Companhia das Letras, 1999. 
Esta revista forma parte del acervo de la Biblioteca Jurídica Virtual del Instituto de Investigaciones Jurídicas de la UNAM www.juridicas.unam.mx

http://biblio.juridicas.unam.mx

MACEDO / PICCOLO

Schopenhauer, ${ }^{34}$ Rousseau, ${ }^{35}$ Fichte, ${ }^{36}$ Aristotle, ${ }^{37}$ Stuart Mill, ${ }^{38}$ Hume, ${ }^{39}$ Hegel ${ }^{40}$ and later Husserl, ${ }^{41}$ Frege, ${ }^{42}$ Kant, ${ }^{43}$ etcetera. The following generations would continue the same tradition of structuralist study of an author "according to Gueroult's order of reasons", (i.e, according to the internal logic of the argument) at least as a starting point for philosophical interpretation. The lack of interest in the Philosophy of Law was notable in the works produced. Exception to this was Tércio Sampaio Ferraz Jr, who eventually managed to make his effort of structurally reading the thoughts by Emil Lask during his $\mathrm{PhD}$ in Germany (Mainz). ${ }^{44}$

The model created at USP marked the scholarly development of philosophy in Brazil. Thus, despite the existence of high-level philosophers and historians of philosophy in other states, such as Henrique de Lima Vaz (1921-2002), Raul Landim (1939-), Guido Antônio de Almeida (1939-) in Rio de Janeiro, Gerd Bornheim (1929-2002), Ernildo Stein

34 Cacciola, M. L. M. O.,"O intuitivo e o abstrato na filosofia de Schopenhauer", in Salles da Silva, João Carlos (org.), Schopenhauer e o idealismo alemão, Salvador, Quarteto, 2004.

35 Prado Jr., B., "O discurso do século e a crítica de Rousseau", Almanaque, São Paulo, n.1, 1976; Fortes, L. R. S., Rousseau: da teoria à prática, São Paulo, Ática, 1976.

36 Torres Filho, R. R., O espirito e a letra: a crítica da imaginação pura em Fichte, São Paulo, Ática, 1975.

37 Pereira, O. P., Ciência e dialética em Aristóteles, São Paulo, UNESP, 2001.

38 Giannotti, J. A., John Stuart Mill: o psicologismo e a fundamentação lógica, doctoral thesis, 1953.

39 Monteiro, J. P., Hume e a epistemologia, São Paulo, UNESP, 2009.

40 Arantes, op. cit.

41 Moura, op. cit.

42 Santos, L. H. L. Dos, $O$ olho e o microscópio: a gênese e os fundamentos da lógica segundo Frege, São Paulo, Nau Editora, 2008.

43 Terra, R., Passagens: estudos sobre a filosofia de Kant, Rio de Janeiro, UFRJ, 2003.

44 See interview with Nobre, M.; Rego, J. M. (ed.), Conversas com filósofos brasileiros, São Paulo, Ed. 34, 2000, p. 277. 
Esta revista forma parte del acervo de la Biblioteca Jurídica Virtual del Instituto de Investigaciones Jurídicas de la UNAM www.juridicas.unam.mx

http://biblio.juridicas.unam.mx

REMARKS ON THE PHILOSOPHY OF LAW IN BRAZIL

(1934-) and Balthazar Barbosa Filho (1947-2007) in the state of Rio Grande do Sul, among others, ${ }^{45}$ the reference of the School of Philosophy of USP spread it out to other portions of Brazil. The dissemination of the new technical standard of philosophical or historical-philosophical production gained momentum with the creation of the Center of Logic and Epistemology (CLE), belonging to the Department of Philosophy of the University of Campinas (UNICAMP). ${ }^{46}$ The CLE is designed and organized in 1976 and officially introduced at UNICAMP in 1977 by Professor Oswaldo Porchat Pereira (1933-). This center brought together philosophers from several Brazilian cities, hitherto scattered and without much connection in thematic seminars on epistemology and several philosophical themes, including political philosophy, moral philosophy, metaphysics, philosophy of language and logic, etcetera. In lieu of a classic congress, with keynote speakers, and few participants, these seminars have introduced an interactive and philosophical debate rather experienced in Brazil until then. ${ }^{47}$ This experience consisted of an important moment of self-criticism to the exaggerations of the structural method, which somehow constrained USP's initiatives towards producing a philosophical and autonomous thought. ${ }^{48}$ Even today, it plays an important and key role in the Brazilian philosophical production, although it has not produced relevant works in the area of philosophy of law.

Later in 1983 the Brazilian Association of Graduate Programs in Philosophy (ANPOF) was founded, bringing to-

45 The works of authors quoted include: Lima Vaz, H., Escritos de filosofia I: problemas de fronteira, São Paulo, Loyola, 1986; Landim, R,. Evidência e verdade no sistema cartesiano, São Paulo, Loyola, 1998; Bornheim, G,. Metafísica e Finitude, São Paulo, Perspectiva, 2001; Stein, E., Seis estudos sobre ser e tempo, Petrópolis, Editora Vozes, 2005.

46 In charge of publishing three major philosophy journals: Cadernos de História da Filosofia da Ciência, Revista Manuscrito and Coleção CLE.

47 Nobre, op. cit. See Balthazar Barbosa's interview in p. 406.

48 Ibidem, pp. 119-144, 337-372. See Oswaldo Porchat Pereira's and Paulo Arantes's interviews. 
Esta revista forma parte del acervo de la Biblioteca Jurídica Virtual del Instituto de Investigaciones Jurídicas de la UNAM www.juridicas.unam.mx

http://biblio.juridicas.unam.mx

MACEDO / PICCOLO

gether all the courses for Masters and Doctors of Philosophy in Brazil, accredited by CAPES, an agency of the Ministry of Education responsible for higher education. This new entity has allowed for national meetings, unifying and standardizing a philosophical style brought forward by USP's School of Philosophy.

\section{The Tradition of Legal Philosophers and the Brazilian Institute of Philosophy (IBF). Miguel Reale: A New CHAPTER IN THE PHILOSOPHY OF JURISTS}

As to legal philosophy specifically, the tradition of the "jurists' philosophical thought" did not cease upon the beginning of the twentieth century. In fact, it remains alive and hegemonic until the 1930s, when it was virtually replaced by the philosophy taught at universities. The key figure of this tradition, the most influential philosopher of law in the Brazilian legal environment of the second half of the twentieth century is surely the Professor Miguel Reale (1910 2006). In this period, he became the most renowned Brazilian philosopher worldwide, and his works were translated into Italian and Spanish. Typical example of an interdisciplinary man of letters, he synthesized various characteristics of the mode of thought he represents. He was a philosopher, jurist, educator, lawyer, journalist, Brazilian poet, member of the Brazilian Academy of Letters, political, ideologist and legislator (he drafted the Brazilian Civil Code of 2002).

In 1932, Miguel Reale began an early intellectual activity, becoming one of the main ideologists and founders, along with Plinio Salgado (1895-1975), of the Brazilian Integralismo (Ação Integralista Brasileira), a Brazilian version of fascist thought that had its heyday in the 1930s. Integralismo also incorporated other important intellectual philosophers, such as Goffredo da Silva Telles Junior (1915-2009), jurist philosopher from USP Law School, ${ }^{49}$ 
Esta revista forma parte del acervo de la Biblioteca Jurídica Virtual del Instituto de Investigaciones Jurídicas de la UNAM www.juridicas.unam.mx

http://biblio.juridicas.unam.mx

REMARKS ON THE PHILOSOPHY OF LAW IN BRAZIL

Roland Corbisier (1914-2005), jurist and philosopher), 50 Álvaro Vieira Pinto (1909-1987, physician, physicist and mathematician), and others. At that time, he produced some of his earliest texts permeated by an authoritarian and critical thinking of liberalism. ${ }^{51}$ Over the years, his political engagement grew apart of fascist thoughts, but it remained loyal to an authoritarian and conservative thought. In 1969, he was appointed by President Artur da Costa e Silva for the "High Level Commission", in charge of reviewing the 1967 Constitution. This work delivered the wording of the Constitutional Amendment No. 1, October 17, 1969, which consolidated the Military Regime in Brazil, restricting many civil and political rights. It was, de facto, a new constitution written by the Military Regime.

Alongside the collection of educational and dissemination works that gave him notoriety (which are still sold all around), 52 Reale can be seen as a "free thinker" of the philosophy of law compared to authors who valued the rigors of a more "technical" and more academic philosophy, but has an undeniable influence on the Brazilian legal and philosophical thinking and style. According to Reale's culturalistic approach (often called Culturalismo) Law is not a natural fact, but a cultural product marked by its connection to social values. Thus science of law should not follow the methodology of natural sciences, but rather from social sciences. His Tridimensional Theory of Law, combin-

Telles Jr., G. da S., Iniciação na ciência do direito, 4th ed., São Paulo, Saraiva, 2008. And also Telles Jr., G. da S., Direito quântico: ensaios sobre o fundamento da ordem jurídica, 7th ed., São Paulo, Ed. Juarez de Oliveira, 2003.

50 Corbisier, R., Filosofia politica e liberdade, Rio de Janeiro, Paz e Terra, 1978.

51 Pinto, A. V., Consciência e realidade nacional, R J, Instituto Superior de Estudos Brasileiro, 1960.

52 For example, Reale, M., Filosofia do direito, São Paulo, Saraiva, 1953; Reale, M., O Direito como experiência, São Paulo, Saraiva, 1968; Reale, M., Lições preliminares de direito, São Paulo, Saraiva, 1973. some of them translated to Spanish, French and Italian. 
Esta revista forma parte del acervo de la Biblioteca Jurídica Virtual del Instituto de Investigaciones Jurídicas de la UNAM www.juridicas.unam.mx

http://biblio.juridicas.unam.mx

MACEDO / PICCOLO

ing influences of Radbruch's neo-Kantianism and the notions of Lebenswelt and intentionality of Husserl, brings forward an overcoming of the unilateral character of positivism (in the broad sense) prevailing in the Brazilian Academies of law, treating Law as a phenomenon that has three dimensions: fact, value and norm. For him sociologism (for example Leon Duguit), Normativism (for example Kelsen) and Natural Law (for example Jean Maritain) offered one-sided view of law. Reale's tridimensional theory is based on an eclectic fusion of these three main sources of modern jurisprudence and tried to overcome them stating that fact, value and norm should be viewed in a dialectical and dynamics way ("dialectics of complementarity"). For Reale values are historical products. However, once created and culturally accepted, they become "axiological invariables" and affect the law of a community. Positive Law is for him a fact that should be analyzed from its three dimensions. Thus the values become historically concrete in facts and inter subjective relationships normatively regulated. His key concept to achieve that is the not always clear concept of dialectics. This conception of Law underpinned the classes of Introduction to Law Studies for many years. Only very recently, it has lost its leading role in the academic study of Philosophy of Law. His philosophical syncretism often makes it hard for the interpreter to understand clearly his ideas. As Tércio Sampaio Ferraz Jr. diplomatically argues, the production and the courses offered by Professor Miguel Reale were profoundly different from those prevailing at the School of Philosophy of USP. "Once, I told Celso (Lafer) that the seminars organized by Professor Miguel Reale had nothing to do with the study of philosophy, and he said I was being biased. In fact, the study I was used to in the School of Philosophy was the one oriented by the point of view of French structuralists, was about studying History of Philosophy, studying the Philosophical Systems, as strictly as possible, while Miguel Reale's style was completely open-minded. The course he had been offering 
Esta revista forma parte del acervo de la Biblioteca Jurídica Virtual del Instituto de Investigaciones Jurídicas de la UNAM www.juridicas.unam.mx

http://biblio.juridicas.unam.mx

REMARKS ON THE PHILOSOPHY OF LAW IN BRAZIL

at that time, for example, was about Vico, but there was no concern with rigor in the interpretation of his philosophical system; what really mattered was thinking on the issues raised by Vico. At first, I found it weird, but little by little, I perceived that he was simply doing something different and why not?"53. Reale's undeniable intellectual leadership made him the ideal example of rhetorical philosopher, heir of the old lawyeristic style, a maximum representative of the spirit pejoratively described as "philosophizing" (filosofante) by philosophers from the School of Philosophy of USP. The political, ideological and methodological contrast would mark out the distances between the "styles" of philosophizing, and would give rise to critical answers from Reale himself, who expressed so after the opening of one of the philosophy congresses he promoted: "Certain people used to think something thought elsewhere were against this initiative, to the extent that they declared that the History of Philosophy in Brazil was nothing else other than a sequence of the influences received, and its mentors had arrogantly denied the title of philosophers, nicknaming us "philosophizers". 54

In 1949, Reale founded the Brazilian Institute of Philosophy (Instituto Brasileiro de Filosofia - IBF) which was very influential among Brazilian Intellectuals and served as an institutional alternative to USP School of Philosophy. As Reale put it: "In 1949, with the support of some thinkers from government or private universities, I found it critical to create an entity that would be able to entwine our cultivators of philosophy for a major national dialogue. This was the origin of the Brazilian Institute of Philosophy, with the creation of the Brazilian Journal of Philosophy (Revista Brasileira de Filosofia - RBF), as essential organ of communication, without preference for any doctrine, and open to collaboration with all stakeholders, whether or not they be-

53 Nobre, op. cit., p. 249. Translation mine.

54 Reale, M., A filosofia no Brasil, 2002. Available at http://www. miguelreale.com.br/artigos/filobras.htm. Translation mine. 
Esta revista forma parte del acervo de la Biblioteca Jurídica Virtual del Instituto de Investigaciones Jurídicas de la UNAM www.juridicas.unam.mx

http://biblio.juridicas.unam.mx

MACEDO / PICCOLO

longed to the university staff. Last year (2001), such journal celebrated half a century of existence, with a quarterly publication, to date, of 206 issues, each with about one hundred and twenty pages". 55

IBF organized some national congresses of philosophy ${ }^{56}$ and congregated intellectuals from various philosophical and ideological matrixes, especially of different "philosophical styles". In a historical account, Reale notes that "IBF congregated thinkers of all doctrines, from the Hegelian dialectic of Djacir Menezes (1907-1996) to Blondel's "intuitionism of action" followed by João de Scantimburgo (1915-). As founder of IBF, I could work with the wonderful team made up by Luis Washington Vita (1921-1968), Vicente Ferreira da Silva (1916-1963), Renato Cirell Czerna (1922-2005), Heraldo Barbuy (1913-1979), Vilém Flusser (1920-1991), Milton Vargas (1914-2011), Teófilo Siqueira Cavalcanti, Roque Spencer Maciel de Barros (1927-1999), Adolpho Crippa (1929-2000) and Lourival Vilanova (1915-). The team was later strengthened by Antonio Paim (1927-2011). ${ }^{57}$ Vicente is indisputably the greatest existential metaphysician of the Portuguese language. Luis Washington was the great architect of the union of Brazilian and Portuguese thinkers, which later culminated with the foundation of the Institute of Portuguese-Brazilian Philosophy". 58

The IBF and the Brazilian Journal of Philosophy (RBF) remained alive, especially through the 1980s, bringing together thinkers from diverse backgrounds, especially those

55 Idem.

56 Reale took part directly in the organization of seven Brazilian Congresses of Philosophy (1950 to 2002) and the VIII Interamerican Congress of Philosophy (Brasília, 1972).

57 Main works related to the Philosophy of Law by: Menezes, D., Tratado de filosofia do direito, São Paulo, Atlas, 1980; Vita, L. W., A filosofia no Brasil, São Paulo, Martins, 1950; Czerna, R. C., Pensamento filosofico e juridico de Miguel Reale, São Paulo, Saraiva, 1999.

58 Reale, M., Panorama filosófico brasileiro, 2005. Available at http:// www.miguelreale.com.br/artigos/panfilbr.htm. Translation mine. 
Esta revista forma parte del acervo de la Biblioteca Jurídica Virtual del Instituto de Investigaciones Jurídicas de la UNAM www.juridicas.unam.mx

http://biblio.juridicas.unam.mx

REMARKS ON THE PHILOSOPHY OF LAW IN BRAZIL

disconnected from the tradition inaugurated with the foundation of the school of philosophy at USP. Along with IBF the Higher Institute of Brazilian Studies (Instituto Superior de Estudos Brasileiros - ISEB) also played a unifying role of the Brazilian social thought. ISEB was created in 1955 by an eclectic group of nationalist intellectuals, linked to the Ministry of Education and Culture, empowered with administrative autonomy, freedom of research, opinion and chair, for the study, teaching and dissemination of social sciences. It worked as a center of ideas and its main objective was discussing theories of development and, in principle, the function of validating the action of the State during the administration of Juscelino Kubitschek, President of Brazil from 1956 to 1961).59 From the methodological point of view, although many of its members come from the university, some tension remained with the methodology of USP's group due to accusations of lack of a strict philosophical theoretical framework of some of its members. The philosophers of the group were Miguel Reale, Álvaro Vieira Pinto (1909-1987) and Roland Corbisier (1914-2005) (a graduate from the School of Law of the University of São Paulo and the School of Philosophy of São Bento). These forged a relationship of detachment and scorn with USP's philosophy similar to that forged by IBF's members.

Indeed, the dialogue among IBF and the School of Philosophy, Sciences and Literature at USP intellectuals has always been scarce. Concerning this relationship between the two institutions, Jose Arthur Giannotti (1930-), one of the main voices of School of Philosophy would say: "Although the opposition between the right and the left wing was very polarized, there was much conviviality (members of the ruling class?) among younger groups; grievances were not yet solidified. Due to our French roots, we have developed the

59 Kubitschek is usually viewed as the father of modern Brazil because during his term the favored long-term planning and set high goals for Brazil's development. He started the construction of a new modernist capital, Brasília. 
Esta revista forma parte del acervo de la Biblioteca Jurídica Virtual del Instituto de Investigaciones Jurídicas de la UNAM www.juridicas.unam.mx

http://biblio.juridicas.unam.mx

MACEDO / PICCOLO

tactic of not directly engaging in discussions with Brazilian things: we would be different, would do another kind of philosophy, and this other kind would spread like an oil slick. Therefore, we simply began to ignore publicly what they did - not so much for contempt, but for this difference in style, precisely to check and consolidate our way of being. Sometimes we would "slap each other faces", but that did not produce major consequences on either side". ${ }^{60}$

Hence, educated or professional philosophers had no interest in the philosophical manifestations of their "philosophizing" colleagues, as the legal philosophers who gathered around the Brazilian Institute of Philosophy (IBF) were contemptuously called. From the point of view of those philosophers graduating at USP's School of Philosophy, legal philosophers seemed to be the outcome of the intellectual underdevelopment of a country not culturally emancipated, a victim of the pedantic superficiality and an ideological and methodological syncretism able to merge elements from conflicting schools of thought without feeling compelled to provide explanations to readers. Legal philosophers linked to ISEB and IBF, on the other hand, criticized the "alienation" of Philosophers from the School of Philosophy (USP) in respect to national problems as well as their little interest with Law and its specific problems, often seen as having no philosophical interest or as a mere expression of legal "ideology". They were accused of being excessively driven to very specific philosophical interpretation about History of Philosophy. This excessively technical dimension (i.e, strong concern with accuracy and methods of philosophical interpretation) was later admitted by some of them. Paulo Arantes (1942-), for example, even states that "we were technicians, rather than "philosophers", emphasizing ironically their intellectual obsessions. ${ }^{61}$

This mutual ignorance and indifference, this purposeful lack of dialogue, was further strengthened from the 1960s,

60 Nobre, op. cit., pp. 99-100.

61 Arantes, op. cit., pp. 144. Translation mine. 
Esta revista forma parte del acervo de la Biblioteca Jurídica Virtual del Instituto de Investigaciones Jurídicas de la UNAM www.juridicas.unam.mx

http://biblio.juridicas.unam.mx

REMARKS ON THE PHILOSOPHY OF LAW IN BRAZIL

due to a decisive historical event that would require the ideological positioning of the intellectuals of the time, blowing the differences that already existed: the seizure of power by the militaries in 1964 .

\section{The 1960s: InCREASINGLy Separate PATHS}

The military regime in Brazil began with a coup carried out by the Armed Forces on March 31, 1964 and lasted until 1985. In October of the same year, the government passed the so-called Suplicy Act, extinguishing the Brazilian Union of Students (UNE) and banning any state-level student association. The idea that dictatorship was intended to convey was the defense of democracy against its worst enemies, the communists. The response of some leftist groups in the form of armed struggle gave rise to the hardening and expansion of political repression apparatuses, leaving deep scars in academia and Brazilian intellectuals. Persecution, imprisonment, exile, compulsory retirement affected the lives of many who engaged in philosophy and put the question of democracy at the core of the militancy of many intellectuals who were against dictatorship.

In Sao Paulo, the leftist thought penetrated the School of Philosophy, Sciences and Literature at USP, while the more conservative line, allied with the military regime, resided at the School of Law of the Presbyterian University Mackenzie. Ideological and political tensions became more acute. The Schools of Law of USP, PUC (Pontificia Universidade Católica) and Mackenzie, the most important in Sao Paulo, supplied a number of intellectuals who supported and championed the military dictatorship, including some Professors of Philosophy of Law, such as Miguel Reale and Alfredo Buzaid. In other Brazilian states, an association between Law and the right wing, and the left wing and academic philosophy, was also forged. In these places the law 
Esta revista forma parte del acervo de la Biblioteca Jurídica Virtual del Instituto de Investigaciones Jurídicas de la UNAM www.juridicas.unam.mx

http://biblio.juridicas.unam.mx

MACEDO / PICCOLO

schools were the privileged locus for the production of the conservative thought.

The new political moment aggravated the distance between "jurist-philosophers" and the "academic philosophers" produced by the French mission. Political (and philosophical) thoughts of the right and left wings were in their natural loci, in the schools of Law and Philosophy, respectively. In Sao Paulo, this antagonism was exemplary, as the most prominent representative of "jurist-philosophers", Miguel Reale, directly supported the military regime. In the other Brazilian states, to a lesser degree of intensity, similar biases also occurred.

If there had been a gap between the schools of Philosophy and Law, due to an approach quite apart of philosophical issues, the military regime expanded such gap even further. The obvious tension between the institutional and ideological positions further nurtured the already-existing methodological gap between them. This gap, however, was not only methodological, as major philosophical influences on the Schools of Philosophy, such as Marxism, phenomenology in their French versions of Sartre and Merleau Ponty were less sensitive in the School of Law dominated by an eclectic culturalism that found inspiration in various sources such as Husserl, Stammler and Emil Lask and in the School of Baden.

This context drawn by large brushstrokes has witnessed the development of some works strongly influenced by a kind of reading of the main works of the pre-Hartian legal positivism, especially the thoughts of Hans Kelsen, Norberto Bobbio and, to a lesser degree, the Scandinavian realism of Alf Ross, as well as those thoughts concerned with the issues related to legal logic. Among its representatives are Tarcisio Burity $(1938-2003)^{62}$ and Lourival

62 Burity, T., Kelsen e o direito internacional consuetudinário, João Pessoa, Editora “A União”, 1988. 
Esta revista forma parte del acervo de la Biblioteca Jurídica Virtual del Instituto de Investigaciones Jurídicas de la UNAM www.juridicas.unam.mx

http://biblio.juridicas.unam.mx

REMARKS ON THE PHILOSOPHY OF LAW IN BRAZIL

Vilanova (1915-).63 The latter's work, in this context, must be especially highlighted, since it represents the first systematical effort to build up an analytically inspired theory of norms in Kelsenian fashion. These Kelsen's readings, though possibly questionable, left an impressive mark on the theoretical production in specific areas such as Administrative Law and Tax Law. The latter has surprisingly become one of the privileged fields of publication in the field of legal theory in recent years. ${ }^{64}$

Although the new political environment has not helped mingling what was produced in the schools of philosophy and in the law school, what would better characterize that moment would be the mutual disinterest: the philosophers were not concerned with the studies performed at the Law School, perhaps not even with Law itself - except when it acquired a classic character, such as in the works by Hegel and Kant-, and jurists also ignored what was being produced in the course of philosophy.

Despite significant differences, both movements were adversely affected by the lack of their own national production. In other words, the absence of a Brazilian philosophy, whether general or legal. ${ }^{65}$ The national philosophical production had, over the entire twentieth century, a popularizing and divulging character. ${ }^{66}$ The philosophy of law had no other fate.

63 Vilanova, Lourival, Estruturas lógicas e o sistema de direito positivo, São Paulo, Max Limonad, 1997.

64 Examples are Paulo de Barros Carvalho (1938-), Celso Antonio Bandeira de Mello (1934-), Geraldo Ataliba (1936-1995), and others. On this matter, see also Sundfeld, C. A., "A ordem dos publicistas", REDE, Salvador, num. 1, Jan/Mar 2005.

65 This seems to be a general diagnosis made by a considerable portion of the Brazilian philosophical intellectuality. See Nobre, M. \& Rego, J. M. (ed.), Conversas com filósofos brasileiros, São Paulo, Ed. 34, 2000, especially the testimonials of Paulo Arantes and Bento Prado.

66 As pointed out by Bento Prado Jr.: "Here, we also do Marxism, phenomenology, existentialism, positivism, etc.: but what we usually do is dissemination. These works are neither organized in the proper time of a 
Esta revista forma parte del acervo de la Biblioteca Jurídica Virtual del Instituto de Investigaciones Jurídicas de la UNAM www.juridicas.unam.mx

http://biblio.juridicas.unam.mx

MACEDO / PICCOLO

VII. The Beginning of a Difficult Dialogue and A Risky OVERVIEW of PRESENT MOMENT

From a certain point in our outline of the Philosophy of Law in Brazil of the twentieth century, an interesting fact caused a change of direction. A large number of European and North-American thinkers, of eminently philosophical education, revived the interest in Law. Jürgen Habermas' testimonial on the revaluation of Law is significant: "In Germany the philosophy of law has long ceased to be a matter just for philosophers (...). Indeed, it is no accident that legal philosophy, in search of contact with social reality, has immigrated into law schools. (...) What could once be coherently embraced in the concepts of Hegelian philosophy now demands a pluralistic approach that combines the perspectives of moral theory, social theory, lethal theory, and the sociology and history of law". 67

The expansion of the importance of modern constitutionalism and, in particular, the moral readings of Law, have renewed the interest of philosophers and jurists on common themes. In a sense, the new constitutionalism and the discussion about the role of principles in the interpretation of constitutional law has been the gateway to the philosophical issues in law schools.

On the other hand, the revaluation of the agenda of political philosophy discussions (Theories of Justice) and the moral philosophies, redirected the interest of academic philosophy to legal issues, opening new horizons for a more fruitful dialogue between legal philosophers and academic philosophers. The remarkable impact of the work by John Rawls on the agenda of contemporary political philosophy has also left its impacts in Brazil, where today the texts of

tradition, nor are they arranged within their own system: their cohesion always come from the outside", in Prado Jr., B., Alguns Ensaios, São Paulo, Max Limonad, 1985.

67 Habermas, J., Between facts and norms. Contributions to a discourse theory of law and democracy, MIT Press, Cambridge, 1996, p. X. 
Esta revista forma parte del acervo de la Biblioteca Jurídica Virtual del Instituto de Investigaciones Jurídicas de la UNAM www.juridicas.unam.mx

http://biblio.juridicas.unam.mx

REMARKS ON THE PHILOSOPHY OF LAW IN BRAZIL

major international philosophers, such as Amartya Sen, Ronald Dworkin, Jürgen Habermas and Charles Taylor, are already translated into Portuguese. Moreover, certain problems and legal issues under discussion in our courts, more than ever, require both a technical and philosophical expertise, and awareness of technical legal problems.

On the other hand -and in line with Dworkin's quote provided at the beginning of this chapter - the central themes of philosophy of language were definitely incorporated into the themes of moral philosophy and law, especially after the publication of The Concept of Law $(\mathrm{O}$ Conceito de Direito) and the dominant debate in the philosophy of Anglo-Saxon and continental European law. This fact updated the legal philosophy held "before the linguistic turn" of issues and challenges that prevail in the schools of philosophy. As a case in point is the extent to which the thoughts of H. L. A. Hart, Neil MacCormick and Robert Alexy are linked to the core of the contemporary philosophical debate that revolves around the philosophy of language and authors such as Habermas, Wittgenstein, Heidegger, Gadamer, Searle, Bernard Williams, John Rawls, etc. Coupling this fact to the undeniable process of globalization of legal and philosophical production, and the expansion of technological means of access to discuss the issues at stake in the countries holding the central position in the production of philosophical knowledge, has allowed an agenda of updated national discussions on international debate. Also note that this relatively late process of translating Anglo-Saxon works (started many years before in Latin American Spanish speaking countries, especially Argentina, Colombia and Mexico) has allowed rescheduling theoretical references that were historically related to the Italian (especially Del Vecchio, Norberto Bobbio, Santi Romano) or French production (Duguit, Hauriou) and, to a lesser extent, to the German production, excepting the strong influence of criminal and civil law. This influence started in some regions of the country where the German migration 
Esta revista forma parte del acervo de la Biblioteca Jurídica Virtual del Instituto de Investigaciones Jurídicas de la UNAM www.juridicas.unam.mx

http://biblio.juridicas.unam.mx

MACEDO / PICCOLO

has brought linguistic proximity to this culture (Welzel, Wieacker, etcétera) prevailing in the 60s. Today, by contrast, Claus Roxin, Günther Jakobs e Bernd Schünemman are some of the authors widely studied and discussed in the Brazilian criminal law, and almost nothing is said about American criminological schools. In general, however, we can state that there is an increasing expansion of the influence of Anglo-Saxon legal and philosophical thoughts.

It survives, especially when we consider the reality of mass education that prevails in almost 1,2000 law schools currently in Brazil, a lawyeristic and outdated form of disseminating philosophical fashions from Europe and USA, which is little different from the old general and superficial practices of the past. However, besides this great market of educational dissemination and simplification, a common agenda gradually emerges among those jurists who are more concerned with the demands of academic rigor set by the university ideal of research and rigor. At this point, some arenas of real debate begin to promote publications, congresses and discussions that seek to challenge the historical gap that has arisen between the philosophies of jurists and the university philosophy.

Some signs of this change can be noticed in the vivid market of translations of legal philosophy works, in the vast production of theses on philosophy of Law in the schools of Law, Political Science and Philosophy, with an incipient process of institutional dialogue. Little by little, bookstores of law replace books on philosophy of law with the "philosophical production of jurists, for jurists," bring books written by philosophers, and also by jurists. Several works were direct translated into Portuguese, introducing modern classics hitherto unknown, or who came here through translations into Spanish. These changes have popularized books of philosophy of law with better technical and academic quality, and have served as an element to renew the very model of legal education, still stuck to the lawyeristic traditions dating back to the beginning of last century.

PROBLEMA

Anuario de Filosofía y Teoría del Derecho, Núm. 8, enero-diciembre de 2014, pp. 179-224 
Esta revista forma parte del acervo de la Biblioteca Jurídica Virtual del Instituto de Investigaciones Jurídicas de la UNAM www.juridicas.unam.mx

http://biblio.juridicas.unam.mx

REMARKS ON THE PHILOSOPHY OF LAW IN BRAZIL

It should be noted that the Brazilian Association of Graduate Programs in Philosophy (ANPOF) has recently created thematic groups on Theories of Justice, Philosophy, Law, Ethics and Political Philosophy, bringing together law and philosophy researchers. Some publications also begin to reflect this convergence. Also from an institutional point of view, it should be noted that the Philosophy of Law in Brazil gradually comes out of a state of complete seclusion, as compared to other Latin American countries. With rare exceptions, Miguel Reale being the most evident one, few Latin American authors are read in Brazil, and few Brazilians exert any influence in other countries. The academic exchange between Brazil and Latin America is still embryonic and lacks prestige. The same cannot be said with respect to other countries like Argentina with a tradition of heavier studies on philosophy of law and great impact on other Spanish-speaking countries. This is the case of Genaro R. Carrió (1922-1997), Eugenio Buligyn (1931-), Ernesto Garzón Valdez (1927-), Carlos E. Alchourrón (1931-1996), Carlos Santiago Nino (1943-1993), inter alia. Moreover, these and other intellectuals have played a key role as promoters of international exchange, especially in English-speaking countries, which took longer to occur in Brazil.

The perspectives of the present are always limited for a proper evaluation of identifiable changes in the panorama of the Philosophy of Law in Brazil. In the short term, it is not easy to spot the effects of these intermingled agendas between the philosophy of philosophers and philosophy of jurists. Whereas the interchange between Brazilian jurists and European and North American universities has grown stronger, renewing the methodological paradigms of theoretical research on law, there are few institutionalized channels for dialogue and collaboration between colleges of law and philosophy in Brazil. The syllabuses are usually apart from each other, the methodological division is still very strong and there is even a professional break-up, since 
Esta revista forma parte del acervo de la Biblioteca Jurídica Virtual del Instituto de Investigaciones Jurídicas de la UNAM www.juridicas.unam.mx

http://biblio.juridicas.unam.mx

MACEDO / PICCOLO

very few professors of philosophy of law are entirely devoted to academic work.

This is a fact that has great influence on the type of educational and superficial literature that can be found in bookstores in Brazil. This large amount of "manual-like" or introductory works on the Philosophy of Law has grown at a startling rate thanks to an important sociological factor: a booming number of law schools in Brazil in recent years. From 165 colleges in 1991, Brazil now has over 1,200 in 2012. Every year, around 120,000 new law graduates come out of colleges and universities. The opportunities offered by the publishing market and the small academic community guided by a stricter philosophical style has promoted the survival of the old lawyeristic style and the survival of its more contemporary forms, both marked by doxographic compilation, linear summary of ideas, and the "superficial" reading of reference authors. Evidently, the new fashions are distinguished from those of the past, but the mode of appropriation remains essentially untouched.

Among the philosophical trends lying in this syncretically divided philosophical and sociological-legal world, there is room for a methodologically eclectic production, with influences of the French structuralism of Foucault, Derrida, Deleuze, the Frankfurt School, Adorno Horkheimer, Marcuse, Habermas, systems theory, Niklas Luhmann and Günther Teubner and the Marxism. Critical Legal Studies has had some limited influence in Brazilian Legal Academia. However, it is worth commenting the thinking developed by Roberto Mangabeira Unger (1947-). Brazilian citizen with a degree from the Federal University of Rio de Janeiro, he developed his academic career at Harvard Law School, where he has been teaching for four decades. There, along with Duncan Kennedy, Mark Tushnet and Morton Horwitz, he was one of the main characters of the Critical Legal Studies, a movement that marked the North-American legal thought, mainly in the 1970s and 1980s. Unger wrote many books on social theory, legal 
Esta revista forma parte del acervo de la Biblioteca Jurídica Virtual del Instituto de Investigaciones Jurídicas de la UNAM www.juridicas.unam.mx

http://biblio.juridicas.unam.mx

REMARKS ON THE PHILOSOPHY OF LAW IN BRAZIL

thought, economic thought, political alternatives, and philosophy, in which he develops the ideals of a radical democratic society open to constant institutional experimentalism. One of his main theoretical focus is on how to plan transformative politics reconciling with new alternative arrangements for economic development. His contribution on legal theory was focused on criticizing the hegemonic methodological consensus in contemporary thought. Interestingly enough, Mangabeira Unger is a thinker of Law who is out of the Brazilian academic circles. Although he may be the most quoted Brazilian law theorist (also because he writes in English), his theoretical influence is greater abroad than in Brazil.

In the context of the 1970 s, we should draw attention to the presence and influence of Luis Alberto Warat (1941-2010), an Argentinean jurist, rooted in Brazil, professor and one of the founders of the Program of Postgraduate Studies in Law at the Law School of the Federal University of Santa Catarina. His presence (and, in particular, his works on law and language, legal education and legal epistemology) along with a new generation of jurists dedicated to legal theory, turned this program into a new national reference, especially for critical legal studies and Alternative Use of Law (Uso Alternativo do Direito). The latter has been more closely linked to legal practice than to the formal legal education.

Although we may escape the scope of this paper if we analyze legal sociology in Brazil in the twentieth century, it is interesting to note that a phenomenon probably similar to that described about philosophy has enabled a mingling of research done by sociologists, jurists and sociologists of law. Several protagonists of this movement in Brazil, including José Eduardo Faria (1949-), Joaquim Arruda Falcão (1943-), José Reinaldo de Lima Lopes (1952-), Celso Campilongo (1957-), Cláudio Souto (1931-), are also intellectuals who are responsible for teaching and publishing 
Esta revista forma parte del acervo de la Biblioteca Jurídica Virtual del Instituto de Investigaciones Jurídicas de la UNAM www.juridicas.unam.mx

http://biblio.juridicas.unam.mx

MACEDO / PICCOLO

works in the field of philosophy of law. 68 The groups of study include the Work Group Law and Society, affiliated with the Brazilian Association of Graduate Studies and Research on Social Sciences which held, until 1989, annual meetings with groups of study, professors and researchers concerned with the critical study of the relationship between law, sociology, politics and philosophy; the Alternative Law Institute (Instituto de Direito Alternativo), which organized several lectures and conferences, disseminating alternative practices of Law; the Group of Justices from the State of Rio Grande do Sul (Grupo de Magistrados Gaúchos), a center set up to discuss Alternative Law and the Association of Judges for Democracy, which sought to raise the awareness of judges on their protective function for human rights and instruments of emancipation of less affluent social groups.

It is also worth noting that the political struggle against the dictatorship aroused a heated debate and stimulated the production of the Brazilian social and theoretical thought on the topic of legitimacy and democracy. Thus, the efforts from intellectuals in the fields of social sciences, history, philosophy and law produced important theoretical works on the Brazilian reality and had repercussions on the national jurisprudential agenda. ${ }^{69}$ This is also one of the reasons why Norberto Bobbio's (as well as Antonio Gramsci's) books would become very popular in Brazil. The other reason is the strong influence exerted by the Kelsenian positivism that the Italian author helped disseminate.

68 Their works include: Faria, J. E., Sociologia Jurídica, direito e conjuntura, São Paulo, Saraiva, 2010; Falcão, J. A. \& Souto, C. (orgs.), Sociologia e Direito, São Paulo, Livraria Pioneira, 1980; Campilongo, C. F., Direito na sociedade complexa, São Paulo, Max Limonad, 2001; Souto, C., Tempo do direito alternativo, Porto Alegre, Livraria do Advogado, 1997.

69 Among them Cardoso, op. cit.; Weffort, F., Por que Democracia?, São Paulo, Ed. Brasiliense, 1984; Coutinho, C. N., A democracia como valor universal, 2nd ed., Rio de Janeiro, Salamandra, 1984. 
Esta revista forma parte del acervo de la Biblioteca Jurídica Virtual del Instituto de Investigaciones Jurídicas de la UNAM www.juridicas.unam.mx

http://biblio.juridicas.unam.mx

REMARKS ON THE PHILOSOPHY OF LAW IN BRAZIL

Also as part of research in law schools, new institutions emerge suggesting the increasing complexity and diversity of the Brazilian legal and philosophical thinking, such as ABRAFI (Associação Brasileira de Filosofia e Sociologia do Direito - Brazilian Association of Philosophy of Law and Sociology of Law), founded in 2001; the Jacques Maritain Institute of Rio Grande do Sul - which is dedicated to the dissemination of Catholic concepts, inspired by the works of his patron Jacques Maritain, as well as on the works of John Finnis-, as well as the reborn Brazilian Institute of Philosophy headed by Tércio Sampaio Ferraz Jr. and Celso Lafer. Also in a convergent way, the Brazilian Institute of History of Law (Instituto Brasileiro de História do Direito IBHD), founded in 2002, has been organizing and promoting courses, conferences, seminars, publications, research projects and congresses to encourage discussion on History of Law and related fields. The research group Law and Democracy, created by the Brazilian Center for Analysis and Planning (Centro Brasileiro de Análise e Planejamento CEBRAP), a very prestigious research center founded in 1969 by Fernando Henrique Cardoso (sociologist and former Brazilian President) and other influential Brazilian Social theorists, has been bringing together scholars interested in theory of Law from the schools of law and philosophy around a search inspired by Habermas' theory of democracy and Law.

Finally, alongside these institutional efforts, it should be noted that some works and individual teaching efforts in the field of philosophy of Law have contributed to the expansion and sophistication of the Brazilian legal philosophical production. Some works of applied theory of Law also represent the result of advancing legal philosophy discussions in Brazil, especially in the field of constitutional theory and in particular in the field of interpretation of Law. ${ }^{70}$

70 The following represent these efforts: Silva, L. V. A. da (org.), Interpretação constitucional - Teoria \& direito público, São Paulo, 
Esta revista forma parte del acervo de la Biblioteca Jurídica Virtual del Instituto de Investigaciones Jurídicas de la UNAM www.juridicas.unam.mx

http://biblio.juridicas.unam.mx

MACEDO / PICCOLO

Many of those authors are influenced by the thoughts of Robert Alexy, Ronald Dworkin, Joseph Raz, among others. Several authors are engaged in these efforts, but it may be still too early to judge their outcomes. Nevertheless, it should be noted that these efforts are seen in several Brazilian states, shifting their focus from what happened in the past, when few developed states virtually monopolized the production and dissemination of the Philosophy of Law. Nonetheless, production is still very uneven in terms of quality and methodological commitments.

One can assume, and it is desirable to expect, that these individual efforts mark a new stage in the production of Philosophy of Law in Brazil, institutionalizing it, professionalizing it, making it more technical and less amateur or dilettante, directing its discussions on Brazilian legal themes. However, this scenario translates better a prospective optimism than a consolidated reality. Globalization has posed challenges to the old ambitions of producing a genuinely national philosophy. Perhaps because of this, the old ambition of some Brazilian legal experts regarding the formation of a Brazilian philosophy of law should be replaced by an ambition to establish a philosophical and legal theory directly engaged and interested in the Brazilian legal reality.

VIII. BIBLIOGRAPHY

ADORNO, S., Os aprendizes do poder: o bacharelismo liberal na politica brasileira, Rio de Janeiro, Paz e Terra, 1988.

Malheiros, 2005; Ávila, H. De, Teoria dos princípios, São Paulo, Malheiros, 2003; Vieira, O. V., A Constituição e sua reserva de Justiça, São Paulo, Malheiros, 1999; Dimoulis, D., Positivismo jurídico: introdução a uma teoria do direito e defesa do pragmatismo jurídico-politico, São Paulo, Método, 2006; Macedo Jr, R. P. \& Barbieri, C. H. C.(orgs.), Direito e interpretação: racionalidades e instituições, São Paulo, Saraiva, 2011. 
Esta revista forma parte del acervo de la Biblioteca Jurídica Virtual del Instituto de Investigaciones Jurídicas de la UNAM www.juridicas.unam.mx

http://biblio.juridicas.unam.mx

REMARKS ON THE PHILOSOPHY OF LAW IN BRAZIL

ARAnTES, P. E., "O bonde da Filosofia. Aspectos da cultura filosófica uspiana nos últimos anos da Rua Maria Antonia (1965-1968), in LoschIAVO DOS SANTOS, Maria Cecília (org.), Maria Antonia: uma rua na contramão, São Paulo, Nobel, 1988.

ARANTES, Um departamento francês de ultramar, estudos sobre a formação da cultura filosófica uspiana (uma experiência nos anos 60), São Paulo, Paz e Terra, 1994.

ARANTES, Hegel: a ordem do tempo, 2nd ed., São Paulo, Hucitec, 2000.

ÁvilA, H. De, Teoria dos princípios, São Paulo, Malheiros, 2003.

BARros, R. S. M., A ilustração brasileira e a idéia de universidade, São Paulo, EDUSP, 1927.

Bonavides, P., Reflexões: Politica e Direito, São Paulo, Malheiros, 1998.

Bornheim, G., Metafisica e Finitude, São Paulo, Perspectiva, 2001.

BURITY, T., Kelsen e o direito internacional consuetudinário, João Pessoa, Editora "A União", 1988.

CACCIOLA, M. L. M. O., "O intuitivo e o abstrato na filosofia de Schopenhauer", in SALlES DA SILVA, João Carlos (org.), Schopenhauer e o idealismo alemão, Salvador, Quarteto, 2004.

Campilongo, C. F., Direito na sociedade complexa, São Paulo, Max Limonad, 2001.

CARDoso, F. H., Autoritarismo e Democratização, Rio de Janeiro, Paz e Terra, 1975.

Coutinho, C. N., 2nd. ed., A Democracia como valor Universal, Rio de Janeiro, Salamandra, 1984.

Chauí, M., A Nervura do Real - Imanência e Liberdade em Espinosa, São Paulo, Companhia das Letras, 1999. 
Esta revista forma parte del acervo de la Biblioteca Jurídica Virtual del Instituto de Investigaciones Jurídicas de la UNAM www.juridicas.unam.mx

http://biblio.juridicas.unam.mx

MACEDO / PICCOLO

Coelho, L. F., 3rd ed., Teoria critica do direito, São Paulo, Del Rey, 2002.

CORBISIER, R., Filosofia politica e liberdade, Rio de Janeiro, Paz e Terra, 1978.

Costa, J. C., Contribuição à história das idéias no Brasil, Rio de Janeiro, José Olympio, 1956.

Czerna, R. C., Pensamento filosofico e juridico de Miguel Reale, São Paulo, Saraiva, 1999.

Dimoulis, D., Positivismo jurídico: introdução a uma teoria do direito e defesa do pragmatismo jurídico-politico, São Paulo, Método, 2006.

Dworkin, R., The Philosophy of Law, New York, Oxford University Press, 1977.

FAusto, R., Dialética marxista, dialética hegeliana, Rio de Janeiro, Paz e Terra, 1997.

FARIA, J. E., Sociologia Jurídica, direito e conjuntura, São Paulo, Saraiva, 2010.

FARIA, Campilongo C. F., Sociologia jurídica no Brasil, Porto Alegre, Fabris, 1991.

FAlCÃo, J. A. \& Souto, C. (orgs.), Sociologia e direito, São Paulo, Livraria Pioneira, 1980.

FERRAZ JR., T. S., Introdução ao estudo do direito, São Paulo, Atlas, 1988.

FERRAZ JR., "A filosofia do direito no Brasil", Revista Brasileira de Filosofia, São Paulo, vol. XLV, Fasc. 197 - January-February-March, 2000.

FERRAZ JR., Estudos de filosofia do direito, São Paulo, Atlas, 2002.

Ferreira, W., Princípios de legislação social e direito judiciário do trabalho, São Paulo, Freitas Bustos, 1938.

FORTES, L. R. S., Rousseau: da teoria à prática, São Paulo, Ática, 1976. 
Esta revista forma parte del acervo de la Biblioteca Jurídica Virtual del Instituto de Investigaciones Jurídicas de la UNAM www.juridicas.unam.mx

http://biblio.juridicas.unam.mx

REMARKS ON THE PHILOSOPHY OF LAW IN BRAZIL

GiannotTI, J. A., John Stuart Mill: o psicologismo e a fundamentação lógica, doctoral thesis, 1953.

GiannotTi, Certa herança marxista, São Paulo, Cia. das Letras, 2000.

GOLDSCHMIDT, V., "Remarques sur la méthode structurale em histoire de la philosophie", Revista Manuscrito, v. V, n. 2, abr. 1982, Campinas, 1982.

HABERMAS, J., Between Facts and Norms. Contributions to a Discourse Theory of Law and Democracy, MIT Press, Cambridge, 1996.

LAFER, C., A Reconstrução dos direitos humanos, São Paulo, Companhia das Letras, 1988.

LAMOUNIER, B., "Formação de um pensamento político autoritário na Primeira República. Uma interpretação", in FAusto, B. (org.), História Geral da Civilização Brasileira, - t. III: O Brasil Republicano, Rio de Janeiro, Bertrand, 2o. vol., 1989.

LANDIM, R., Evidência e verdade no sistema cartesiano, São Paulo, Loyola, 1998.

LESsA, P., Estudos de filosofia do direito, Rio de Janeiro, F. Alves, 1912.

LESSA, Dissertações e polêmicas - Estudos jurídicos, Rio de Janeiro, Tipografia do Jornal do Comércio, 1909.

LIMA VAZ, H., Escritos de filosofia I: problemas de fronteira, São Paulo, Loyola, 1986.

LOPES, J. R. L., O direito na história, lições introdutórias, São Paulo, Max Limonad, 2000.

MACEDO JR., R. P., "O método de leitura estrutural", in Macedo Jr., R. P. (org.), Curso de filosofia política, São Paulo, Atlas, 2008. Also available at: http://bibliotecadigital.fgv.br/dspace/handle/10438/2814. 
Esta revista forma parte del acervo de la Biblioteca Jurídica Virtual del Instituto de Investigaciones Jurídicas de la UNAM www.juridicas.unam.mx

http://biblio.juridicas.unam.mx

MACEDO / PICCOLO

MACEDO JR, R. P. \& BARBIERI, C. H. C. (orgs.), Direito e interpretação: racionalidades e instituições, São Paulo, Saraiva, 2011.

Menezes, D., Tratado de filosofia do direito, São Paulo, Atlas, 1980.

MonteIRo, J. P., Hume e a epistemologia, São Paulo, UNESP, 2009.

Montoro, A. F., Estudos de filosofia do direito, 4th ed., São Paulo, Saraiva, 2009.

MourA, C. A. R., "Husserl: Intencionalidade E Fenomenologia", Mente - Cérebro e Filosofia, São Paulo, Editora Duetto, num. 5., 2007.

NADER, P., Filosofia do direito, Rio de Janeiro, Forense, 2000.

Nobre, M. \& REGo, J. M. (ed.), Conversas com filósofos brasileiros, São Paulo, Ed. 34, 2000.

NovAis, F., "Braudel e a "missão francesa", Estudos Avançados, São Paulo,vol. 8, num. 22, Sept.-Dec., 1994.

PAIM, P., História das idéias filosóficas no Brasil, São Paulo, EDUSP, 1974.

PEREIRA, O. P. Ciência e dialética em Aristóteles, São Paulo, UNESP, 2001.

PInTO, A. V., Consciência e Realidade Nacional, RJ, Instituto Superior de Estudos Brasileiro, 1960.

PRADO JR., B., "O discurso do século e a crítica de Rousseau”, Almanaque, São Paulo, num. 1, 1976.

PRADO JR., B., Alguns Ensaios, São Paulo, Max Limonad, 1985.

REAle, M., Filosofia em São Paulo, 2nd ed., São Paulo, Grijalbo, 1976.

REALE, A filosofia no Brasil, 2002. Available at http://www.miguelreale.com.br/artigos/filobras.htm. 
Esta revista forma parte del acervo de la Biblioteca Jurídica Virtual del Instituto de Investigaciones Jurídicas de la UNAM www.juridicas.unam.mx

http://biblio.juridicas.unam.mx

REMARKS ON THE PHILOSOPHY OF LAW IN BRAZIL

REALE, Panorama filosófico brasileiro, 2005. Available at http://www.miguelreale.com.br/artigos/panfilbr.htm.

REALE, Filosofia do direito, São Paulo, Saraiva, 1953.

REALE, O direito como experiência, São Paulo, Saraiva, 1968.

REALE, Lições preliminares de direito, São Paulo, Saraiva, 1973.

RIBAS, A. J., Curso de direito civil brasileiro, Rio de Janeiro, J. R. dos Santos, 1915.

Romero, S., Ensaios de philosophia do direito, Recife, Companhia Impressora, 1885.

Romero, A filosofia no Brasil: ensaio crítico, Porto Alegre, Tipografia de Deutsche Zeitung, 1878.

SANTOS, L. H. L., Dos, O olho e o microscópio: a gênese e os fundamentos da lógica segundo Frege, São Paulo, Nau Editora, 2008.

SchWARTZMAn, S., Formação da comunidade científica no Brasil, Cia Editora Nacional, 1979.

SILVA, L. V. A. da (org.), Interpretação constitucional-Teoria \& direito público, São Paulo, Malheiros, 2005.

Souto, C., Tempo do direito alternativo, Porto Alegre, Livraria do Advogado, 1997.

STEIN, E., Seis estudos sobre ser e tempo, Petrópolis, Editora Vozes, 2005.

SunDFELD, C. A., "A ordem dos publicistas", REDE, num. 1, Salvador, Jan/Mar 2005. Available at $h t t p: / / w w w . d i-$ reitodoestado.com/revis-

ta/REDE-1-JANEIRO-2005-CARLOS\%2OARI\%20SUND FELD.pdf.

TeiXeira de Freitas, A., Código Civil - Esboço, Rio de Janeiro, Typographia Universal de Laemmert, 1864.

TeiXeIRA DE Freitas, Consolidação das Leis Civis, Rio de janeiro, 1857. 
Esta revista forma parte del acervo de la Biblioteca Jurídica Virtual del Instituto de Investigaciones Jurídicas de la UNAM

TEIXEIRA, L., Ensaio sobre a moral de Descartes, São Paulo, Brasiliense, 1990.

TELles JR., G. da S., Iniciação na ciência do direito, 4th ed., São Paulo, Saraiva, 2008.

TELLES JR., Direito quântico: ensaios sobre o fundamento da ordem juridica, 7th ed., São Paulo, Ed. Juarez de Oliveira, 2003.

TERRA, R., Passagens: estudos sobre a filosofia de Kant, Rio de Janeiro, UFRJ, 2003.

TORRES FILHO, R. R., O espirito e a letra: a crítica da imaginação pura em Fichte, São Paulo, Ática, 1975.

VenÂncio Filho, A., Das arcadas ao Bacharelismo, São Paulo, Perspectiva, 1977.

Vianna, Francisco José de Oliveira, Problemas de direito corporativo, Rio de Janeiro, Livraria José Olympio Ed., 1938.

VIEIRA, O. V., A Constituição e sua reserva de Justiça, São Paulo, Malheiros, 1999.

VILANOVA, Lourival, Estruturas lógicas e o sistema de direito positivo, São Paulo, Max Limonad, 1997.

VITA, L. W., A filosofia no Brasil, São Paulo, Martins, 1950.

Weffort, F., Por que Democracia?, São Paulo, Ed. Brasiliense, 1984. 